\title{
LOKABASA
}

Jurnal Kajian Bahasa, Sastra, dan Budaya Daerah serta Pengajarannya

Volume 11, No. 1, April - 2020, Hal. 50-60

p-2338-6193 (print) | e-2528-5904 (online)

Article URL: http://ejournal.upi.edu/index.php/lokabasa

doi: https://doi.org/10.17509/jlb.v11i1

\section{Frasa Eksosentrik dalam Novel Kembang Kembang Petingan Karya Holisoh M.E}

\author{
Leni Maryanika, Yayat Sudaryat \\ Universitas Pendidikan Indonesia \\ lenimaryanika@upi.edu
}

Sejarah Artikel: Diterima (15 Desember 2019); Diperbaiki (20 Januari 2020); Disetujui (05 Februari 2020); Published (30 April 2020)

Bagaimana mengutip artikel ini (dalam gaya APA): Maryanika, L. \& Sudaryat, Y. (2020). Frasa Eksosentrik dalam Novel Kembang Kembang Petingan Karya Holisoh M.E. Lokabasa, 11(1), 50-60. doi: https://doi.org/10.17509/jlb.v11i1.25198

Abstrak: Penelitian ini bertujuan untuk menganalisis dan mendeskripsikan frasa eksosentrik yang meliputi bentuk, struktur, dan semantik (hubungan antarunsur gramatikal) yang terdapat dalam novel Kembang Kembang Petingan karya Holisoh M.E. Penelitian ini menggunakan metode deskriptif dengan pendekatan kualitatif, teknik yang digunakan dalam mengumpulkan data adalah tehnik studi pustaka, dan teknik analisis yang digunakan yaitu teknik analisis unsur langsung. Sumber data yang digunakan adalah novel Kembang Kembang Petingan karya Holisoh M.E. Hasil dari penelitian ini yaitu terdapat 1133 frasa eksosentrik dengan frekuensi 1658 kali, lalu mendeskripsikan tiga hal yaitu (1) bentuk frasa eksosentik yang terdiri atas data 2 jenis frasa yaitu frasa direktif dan relatif, (2) struktur frasa eksosentrik yang memiliki 4 pola utama dan 11 subpola, dan (3) semantik (hubungan makna antarunsur gramatikal) yang terdiri atas 12 hubungan makna antarunsur gramatikal frasa direktif dan 2 hubungan makna antarunsur gramatikal frasa relatif. Berdasarkan hasil penelitian dapat disimpulkan bahwa frasa eksosentrik mempunyai bentuk, struktur, dan hubungan gramatikal antarunsurnya yang berkaitan dengan kajian struktur dan semantik.

Kata Kunci: frasa eksosentrik; Kembang Kembang Petingan

\section{Phrase Exocentric in "Kembang-Kembang Petingan" Novel by Holisoh M. E.}

Abstract: The research aims to analyze and describe exocentric phrase that include the form, stucture, and semantics (the relation between grammatical elements) that contained in the novel Kembang Kembang Petingan by Holisoh M.E. In this study used descriptive method with a qualitative approach. Technique used in collecting data is a literature study. The data analysis technique used in this study is direct elemental analysis techniques. The data source used in this study is Novel Kembang Kembang Petingan by Holisoh M.E. The results of this research have 1133 phrase with 1658 frekuesi and describe three things, (1) exocentric phrase divided into two types of phrase, direktif phrase and relative phrase, (2) stucture of exocentric phrase have four general stucture and eleven substucture, and (3) semantics (the relation between grammatical elements) have twelve relation gramatical of direktif phrase and two relation gramatical of relative phrase in the Kembang novel Kembang Petingan by Holisoh ME. Based on research can be concluded phrase exocentric in Kembang Kembang Petingan novel by Holisoh M.E can be examined in aspects form, stucture, and relation grammatical elements.

Keywords: phrase excocentric; Kembang Kembang Petingan 


\section{PENDAHULUAN}

Rangkaian kata atau frasa dalam kalimat dapat menyebabkan proses komunikasi dalam kehidupan manusia. Komunikasi dapat menggunakan bentuk lisan ataupun tulisan. Dalam komunikasi, bahasa dapat digunakan untuk menyampaikan pesan, ide, perasaan, dan maksud (Sudaryat, 2015, hlm. 126). Tentu saja dalam komunikasi, kata, frasa, dan klausa menjadi sebuah asosiasi yang tidak dapat dipisahkan dalam bentuk kata per kata untuk berkomunikasi.

Kata adalah bahasa terkecil dalam bentuk lisan atau tertulis, (Alwi dalam Sumarni, 2016, hlm. 36). Setiap kata dapat memiliki makna, baik yang disusun oleh satu kata atau satu frasa. Struktur kalimat terdiri atas kumpulan kata-kata, frasa, dan klausa yang dipelajari oleh ilmu kebahasaan yang disebut tata kalimat (sintaks) (Sudaryat, 2014, hlm. 40). Studi sintaksis meneliti mengenai hal struktur kata atau kumpulan kata yang mempengaruhi makna dari pembentukan dalam bentuk kata (Sundari, 2017, hlm. 252). Sintaksis berperan sangat penting dalam keilmuan tata kalimat, termasuk penelitian ini yang meneliti tentang kalimat. Frasa menjadi bahasan yang sering muncul dalam sintaksis (Setyadi, 2017, hlm. 187). Frasa eksosentrik yang tidak memiliki unsur-unsur inti dapat digunakan dalam komunikasi sehari-hari dan banyak juga digunakan untuk menulis sastra.

Ilmu mengenai kebahasaan menjadi hal yang menarik, karena masyarakat tidak dapat lepas dari penggunaan bahasa (Hakim, 2016). Penelitian mengenai frasa lazim dilakukan, itu sebabnya mengapa aspek-aspek mengenai frasa perlu dipelajari. Salah satu masalahnya adalah pemakaian frasa dalam literatur tertulis. Dapat dari bentuk perangkai dan sumbu yang tidak sama dengan pola-pola yang ditentukan. Dengan demikian, sintaksis merupakan salah satu keilmuan yang dapat menjadi dasar teori untuk penelitian frasa sehingga dapat memecahkan masalah. Selain itu, karena sintaksis mencakup unsur-unsur bahasa di mana frasa, klausa, dan kalimat, tentu saja akan memiliki unsur-unsur bahasa yang terkait dengan pola atau aturan tertentu.

Frasa eksosentrik adalah frasa yang distribusi atau perilaku sintaksinya tidak sama dengan unsur-unsurnya (Sudaryat, 2013, hlm. 160). Frasa ini tidak mengandung unsur yang menjelaskan dan dijelaskan unsur pusat dan tambahan. Elemen sama pentingnya, tapi tidak bisa diganti satu dengan yang lain, atau salah satu unsur tidak dapat mewakili frasa yang lain. Ada dua jenis frasa eksosentrik diteliti, yaitu frasa direktif dan frasa relatif. Frasa eksosentrik, diteliti dalam aspek bentuk, struktur dan hubungan gramatikal.

Penelitian frasa pernah dilakukan oleh (Najihah, 2015) yang berjudul "Frasa Eksosentrik dalam Novel Sebelas Patriot Karya Andrea Hirata" yang meneliti mengenai frasa eksosentrik dalam bahasa Indonesia yang mendeskripsikan data frasa eksosentrik dan struktur frasa eksosentrik yang ada dalam objek tersebut. Ada juga "Frasa rélatif dalam "Kumpulan Cerpen OlehOleh Pertempuran Karangan Rukman H. S." (Kajian Struktur dan Semantis)" oleh (Herlis, 2007) menganalisis tentang struktur, dan hubungan gramatikal antarunsur pembentuknya. Selain itu, ada penelitian yang berjudul "Frasa $P a$ ngantét dina Campaka Mangkak Antologi Karya nu Ngarora" oleh (Winarti, 2007). Penelitian ini menedeskripsikan tentang bentuk, struktur, dan hubungan makna gramatikal antarunsur pembentuknya.

Dalam penelitian yang telah diuraikan di atas, tampaknya ungkapan penelitian frasa eksosentrik secara menyeluruh jarang dilaksanakan dalam lingkup bahasa Sunda. Penelitian sebelumnya hanya menganalisis bagian dari frasa eksosentrik. Ada juga yang men- 
deskripsikan frasa eksosentrik, akan tetapi dalam ruang lingkup bahasa Indonesia.

Kemudian, perbedaan penelitian ini dari penelitian yang lainnya yaitu terfokus pada bentuk, struktur frasa karena bentuk-bentuk yang ditemukan dalam struktur atau pola yang tidak sesuai dengan pola tertentu, dan juga objek penelitian yang digunakan berbeda dengan penelitian sebelumnya. Meskipun ada persamaanya dan bentuk frasa yang termasuk frasa direktif dan frasa relatif, tapi dalam data, dan pola pasti ada perbedaan. Terlebih akan ada perbedaan antara struktur frasa dalam bahasa Indonesia dengan frasa bahasa Sunda. Objek yang digunakan dalam penelitian ini berbeda dari penelitian sebelumnya. Dengan demikian, penelitian mengenai Frasa Eksosentrik dalam Karya Sastra Populer penting dilaksanakan.

\section{METODE}

Dalam penelitian ini, termasuk penelitian dengan metode kualitatif. (Sugiyono, 2017, hlm. 9). Metode yang digunakan dalam penelitian ini adalah metode deskriptif, metode yang memiliki tujuan untuk mencari dan memecahkan masalah dengan mengumpulkan data aktual, membuat data papasingan, menganalisis, dan menafsirkan data (Arikunto, 2010, hlm. 225).

Dalam hal ini data penelitian yang dikumpulkan setelah menggunakan teknik studi pustaka, maka data tersebut diolah dan dianalisis. Dalam penelitian ini teknik pengolahan data yang digunakan adalah diidentifikasi, klasifikasi dan analisis data. Klasifikasi data dan identifikasi hasil kemudian dianalisis dengan menggunakan kartu data. Tujuan penggunaan kartu data adalah untuk memproses dengan mudah mencari dan mengisolasi setiap data teks ditemukan dalam sumber data yang termasuk dalam analisis penelitian.
Sebelum proses menganalisis instrumen yang digunakan untuk mengumpulkan data menggunakan kartu data. Kartu data digunakan untuk memasukkan seluruh frasa eksosentrik ditemukan pada kartu data, dan setiap kartu diberi nomor, judul novel, halaman, paragraf. Urutannya didahului dengan judul buku, halaman, paragraf, dan halaman.

Setelah menggunakan data kartu, ada banyak hal yang harus dilakukan diantaranya (1) mengamati lagi data frasa eksosentrik yang telah dikumpulkan, (2) menyusun data frasa eksosentrik secara alfabetis, (3) membuat kelompok kelompok data frasa eksosentrik sesuai dengan bentuk, struktur, dan hubungan gramatikal antarunsur pembentuknya, (4) menganalisis data frasa eksosentrik berdasarkan bentuk, struktur dan hubungan gramatikal antarunsur pembentuknya, (5) mendeskripsikan frasa eksosentrik berdasarkan bentuk, struktur dan hubungan gramatikal antarunsur pembentuknya, (6) membuat interpretasi dan kesimpulan.

\section{HASIL DAN PEMBAHASAN}

Frasa eksosentrik termasuk salah satu jenis frasa yang terdiri dari unsur perangkai dengan unsur sumbu. Dalam novel Kembang Kembang Petingan karya Holisoh M.É. ditemukan frasa eksosentrik yang dapat diamati dalam aspek bentuk, struktur, dan hubungan gramatikal antarunsur pembentuk frasa eksosentrik.

\section{Bentuk Frasa Eksosentrik}

Bentuk frasa eksosentrik, terbentuk dari macam-macam frasa dilihat dari wujud perangkainya. Ada dua macam frasa eksosentrik, yaitu frasa direktif dan frasa relatif (Sudaryat, 2013, hlm.161). Dalam analisinya, frasa direktif lebih banyak digunakan (770 frasa) daripada frasa relatif (430 frasa). Hal ini disebabkan karena bentuk perangkai frasa direktif lebih bayak daripada frasa 
relatif. Bentuk perangkai frasa direktif di antaranya berupa preposisi batan [daripada], di [di], dina [pada], jeung [dan], ka [untuk], kana [ke], keur [sedang], $k u$ [oleh], nepi ka [sampai], $t i$ [dari], dan tina [dari]. Sedangkan bentuk frasa relatif hanya terbentuk dari kata $a(n u)$ [yang] sebagai perangkainya.

\section{Bentuk Frasa Direktif}

Frasa direktif adalah frasa yang kontruksinya terdiri dari dua elemen. Elemen pertama adalah relator (pengikat) atau direktor (perangkai), sedangkan elemen kedua adalah aksis (sumbu). Dengan begitu, frasa ini disebut frasa relator aksis (pengikat aksis), frasa relasional, atau frasa direktif. Frasa direktif dapat didefinisikan frasa yang terdiri dari preposisi dan unsur lainnya adalah kata benda, frasa kata benda, dan kata ganti (Sofyan, 2015, hlm. 263). Menurut hasil penelitian di bawah ini contoh frasa direktif.

1. Lembur Tita mah di lamping gunung (KKP/68/2/1)

[kampung halaman Tita di punggung gunung]

2. Leuwih pantes batan kuring (KKP/89/1/5)

[lebih pantas daripada saya]

3. Nyiar kai jati ka Jepara (KKP/75/1/2)

[mencari kayu jati ke Jepara]

Frasa di lamping gunung [di punggung gunung] dalam contoh (1) terdiri dari preposisi di sebagai perangkai dan frasa lamping gunung [punggung gunung] sebagai sumbu atau aksisnya. Frasa batan kuring [dari pada saya] dalam contoh (2) terdiri dari preposisi batan [dari pada] sebagai perangkai dan kata barang kuring [saya] sebagai sumbu atau aksisnya. Frasa $k a$ Jepara [ke Jepara] pada contoh (3) terdiri dari preposisi sebagai perangkai dan kata benda Jepara [Jepara] sebagai sumbu atau aksisnya. Setiap frasa contoh di atas termasuk frasa direktif karena terdiri dari dua unsur, yaitu perangkai preposisi dan sumbu yang termasuk golongan kata benda. Dalam contoh di atas, semua frasa sesuai dengan teori rujukannya yang terdiri dari preposisi sebagai perangkainya dan kata benda, frasa benda, dan yang tergolong kata benda.

\section{Wanda Frasa Relatif}

Frasa relatif adalah frasa yang terbentuk dari relater $(a) n u$ dan sumbunya yaitu kata ganti, kata kerja, kata sifat, kata, kata waktu, dan frasa preposisi (Sudaryat, 2013, hlm.157). Menurut hasil penelitian di bawah ini contoh frasa relatif.

1. Tara aya апи opénan (KKP/51/12/3)

[tidak pernah ada yang ikut campur]

2. Ramo-ramo gorila nu baradag (KKP/13/4/5)

[jari-jari gorila yang besar-besar]

3. Aya nu batuk tarik naker di lawang panto (KKP/45/3/1)

[ada yang batuk kencang sekali di pintu]

Frasa апи opénan [yang ikut campur] dalam contoh (1) terdiri dari kata sambung relatif anu [yang] sebagai perangkai dan kata kerja opénan [ikut campur] sebagai sumbu atau aksisnya. Frasa nu baradag [yang besar-besar] dalam contoh (2) terdiri dari kata sambung relatif $n u$ [yang] sebagai perangkai dan kata sifat baradag [besar-besar] sebagai sumbu atau aksisnya. Frasa $n u$ batuk [yang batuk] pada contoh (3) terdiri dari kata sambung relatif $n u$ [yang] sebagai perangkai dan kata kerja batuk [batuk] sebagai sumbu atau aksisnya. Setiap frasa contoh di atas termasuk frasa relatif karena terdiri dari dua unsur, yaitu unsur pertama yang berupa perangkai kata sambung relatif 
dan sumbunya yang termasuk kata sifat, kata kerja. Dalam contoh di atas, semua frasa sesuai dengan teori rujukannya yang terdiri dari kata sambung relatif sebagai perangkainya dan kata sifat, kata kerja sebagai sumbunya.

\section{Struktur Frasa Eksosentrik}

Sama dengan bentuknya, frasa direktif dan frasa relatif masing-masing meliliki struktur tertentu, yang dilihat dari unsur-unsur pembentuknya.

\section{Struktur Frasa Direktif}

Frasa eksosentrik kontruksinya terdiri dari dua elemen. Elemen pertama dari relator dan elemen kedua sumbu (Sudaryat, 2013, hlm.161). Struktur frasa direktif seperti di bawah ini. FDir $\rightarrow$ UN-1: Dir + UN-2: Aks.

Struktur frasa direktif terbentuk dari perangkai dan sumbu (Ardianto, 2017, kc. 30). Bentuk perangkai frasa direktif di antaranya berupa preposisi batan [dari pada], di [di], dina [pada], jeung [dan], $k a$ [untuk], kana [ke], keur [sedang], $k u$ [oleh], nepi ka [sampai], ti [dari], dan tina [dari]. Berdasarkan bentuk aksisnya, ditemukan 2 struktur inti frasa diréktif yaitu 1) Prep + Kx dan 2) Prep + FB. Dalam pola (1) miboga 2 sub pola, yaitu seperti di bawah ini.

Pola (1a) Prep + KB

Contoh:

1. Layonna rék ditaékkeun kana ambulan (KKP/159/3/1)

[mayatnya akan dinaikan ke ambulan]

2. Nyiar kai jati ka Jepara (KKP/75/1/2)

[mencari kayu jati ke Jepara]

Frasa kana ambulan [ke ambulan] dan frasa ka Jepara [ke Jepara] dalam contoh di atas termasuk frasa direktif yang memiliki struktur unsur pertama dibentuk oleh preposisi kana [ka] dan preposisi $k a$ [ke] sebagai perangkai. Unsur kedua berupa kata benda ambulan dan Jepara yang merupakan sumbu atau aksisnya. Sama dengan teorinya yang menyatakan bahwa frasa direktif terbentuk dari salah satu sumbunya yang merupakan kata benda seperti conto di atas.

\section{Pola (1b) Prep + KBil \\ Conto: \\ 1. Moal kurang ti genep (KKP/32/1/2) \\ [tidak kurang dari enam] \\ 2. Lamun umur geus kurang ti tilu puluh lima (KKP/101/4/1) \\ [jika umur sudah kurang dari tiga puluh lima]}

Frasa ti genep 'dari enam' dan frasa ti tilu puluh lima 'dari tiga puluh lima' dalam contoh di atas termasuk frasa direktif yang memiliki struktur unsur pertama dibentuk oleh preposisi $t i$ 'dari' sebagai perangkai. Unsur kedua berupa kata bilangan enam dan tiga puluh lima yang merupakan sumbu atau aksisnya. Sama dengan teorinya yang menyatakan bahwa frasa direktif terbentuk dari salah satu sumbunya yang tergolong kata benda yaitu kata bilangan seperti conto di atas.

Selain dari pola 1 , frasa direktif mempunyai pola 2 yaitu Prep + Fx yang terbagi menjadi 2 subpola.

Pola (2a) Prep + FN Contoh:

1. Mun aya nanaon di kamar Mamih (KKP/32/2/3)

[kalau ada apa-apa di kamar Mamih]

2. Ninggal téh di kamar Aa (KKP/134/9/1)

[melihat di kamar Aa]

Frasa di kamar Mamih 'di kamar Mamih' dan frasa di kamar Aa 'di kamar Aa' dalam contoh di atas termasuk frasa direktif yang memiliki struktur unsur pertama merupakan preposisi $d i$ 'di' se- 
bagai perangkai. Unsur kedua berupa frasa benda kamar Mamih dan kamar Aa yang merupakan sumbu atau aksisnya. Sama dengan teorinya yang menyatakan bahwa frasa direktif terbentuk dari salah satu sumbunya yang tergolong frasa benda yaitu kata bilangan seperti conto di atas.

Pola (2b) Prep + FNum

Contoh:

1. Nepi ka lima urang gé hak kuring (KKP/45/4/4)

[sampai lima orang juga hak saya]

2. Moal kurang ti opat ratus rébu (KKP/102/1/3)

[tidak kurang dari empat ratus ribu]

Frasa nepi ka lima urang [sampai lima orang] dan frasa ti opat ratus rébu [dari empat ratus ribu] dalam contoh di atas termasuk frasa direktif yang memiliki struktur unsur pertama merupakan preposisi nepi ka [sampai] dan $t i$ [dari] sebagai perangkai. Unsur kedua berupa frasa bilangan lima urang [lima orang] dan opat ratus rébu [empat ratus ribu] yang merupakan sumbu atau aksisnya. Sama dengan teorinya yang menyatakan bahwa frasa direktif terbentuk dari salah satu sumbunya yang tergolong kata benda yaitu frasa bilangan seperti conto di atas.

Struktur frasa direktif yang paling sering digunakan adalah Prep + KB (584 frasa), struktur frasa diréktif paling sedikit digunakan yaitu Prep + KBil (2 frasa), sisanya Prep + FB (142 frasa) dan Prep + FBil (6 frasa).

\section{Struktur Frasa Relatif}

Frasa relatif adalah frasa yang terbentuk oleh kata sambung relatif (a)nu dan sumbunya yang merupakan kata ganti, kata kerja, kata sifat, kata bilangan, kata benda waktu, dan frasa preposisi. Struktur frasa relatif dapat digambarkan dengan rumus seperti di bawah ini.

FRél $\rightarrow$ UN-1: Rél + UN-2: Aks.

Struktur frasa relatif terbentuk oleh unsur pertama kata sambung relatif anu atau $n u$ sebagai perangkai dan unsur kedua yang merupakan warna kata sebagai aksisnya. Ada tujuh kata warna dan frasa yang ditemukan dalam frasa relatif. Menurut bentuk dan warna sumbunya, ditemukan 2 struktur utama yaitu (3) Krel + Kx dan (4) Krel + Fx. Dalam pola (3) terbagi menjadi 3 subpola seperti di bawah ini.

Pola (3a) Krél + KB

Contoh:

1. Pan nu adé ieu téh (KKP/107/5/1)

[kan yang ade ini teh]

2. $\mathrm{Nu}$ beungeutna siga indo? (KKP/76/8/1)

[yang mukanya kaya indo?]

Frasa $n u$ ade [yang ade] dan frasa $n u$ beungeutna [yang mukanya] dalam contoh di atas termasuk frasa relatif yang memiliki struktur unsur pertama merupakan kata sambung relatif $n u$ [yang] sebagai perangkai. Unsur kedua berupa kata benda ade dan mukanya yang merupakan sumbu atau aksisnya. Sama dengan teorinya yang menyatakan bahwa frasa relatif terbentuk dari salah satu sumbunya yang termasuk kata benda seperti conto di atas.

Pola (3b) Krél + KK

Contoh:

1. Sangkan ulah aya nu asup (KKP/31/14/1)

[sehingga tidak ada yang masuk]

2. Najan aya nu babantu (KKP/171/1/2)

[meskipun ada yang membantu]

Frasa $n u$ asup [yang masuk] dan frasa $n u$ babantu [yang membantu] 
dalam contoh di atas termasuk frasa relatif yang memiliki struktur unsur pertama merupakan kata sambung relatif $n u$ [yang] sebagai perangkai. Unsur kedua berupa kata kerja ade dan mukanya yang merupakan sumbu atau aksisnya. Sama dengan teorinya yang menyatakan bahwa, frasa relatif terbentuk dari salah satu sumbunya yang termasuk kata kerja seperti conto di atas. Pola (3c) Krél + KS

Contoh:

1. Karasa aya nu longsong dina haté (KKP/39/4/2)

[terasa ada yang tidak cemas dalam hati]

2. Taya nu béla? (KKP/163/7/6)

[Tidak ada yang membela']

Frasa nu longsong [yang tidak cemas] dan frasa nu béla [yang membela] dalam contoh di atas termasuk frasa relatif yang memiliki struktur unsur pertama merupakan kata sambung relatif $n u$ [yang] sebagai perangkai. Unsur kedua berupa kata sifat tidak cemas dan membela yang merupakan sumbu atau aksisnya. Sama dengan teorinya yang menyatakan bahwa frasa relatif terbentuk dari salah satu sumbunya yang termasuk kata sifat seperti conto di atas.

Pola (4a) Krél + FN

Contoh:

1. Taya $n u$ peunten genep (KKP/25/7/4) [tidak ada yang nilai enam]

2. Ieu nu nggaran Enok téh? (KKP/86/5/1)

[ini yang namanya Enok]

Frasa nu peunteun genep [yang nilai enam] dan frasa nu ngaran enok [yang namanya Enok] dalam contoh di atas termasuk frasa relatif yang memiliki struktur unsur pertama merupakan kata sambung relatif $n u$ [yang] sebagai perangkai. Unsur kedua berupa frasa nomina nilai enam dan namanya Enok yang merupakan sumbu atau aksisnya. Sama dengan teorinya yang menyatakan bahwa frasa relatif terbentuk dari salah satu sumbunya yang termasuk frasa nomina seperti conto di atas.

Pola (4b) Krél + FNum

Contoh:

1. Nu hiji deui remen ngamar (KKP/11/3/4)

[yang satu lagi sering]

Frasa nu hiji deui [yang satu lagi] dalam contoh di atas termasuk frasa relatif yang memiliki struktur unsur pertama merupakan kata sambung relatif $n u$ [yang] sebagai perangkai. Unsur kedua berupa frasa numeralia satu lagi yang merupakan sumbu atau aksisnya. Sama dengan teorinya yang menyatakan bahwa frasa relatif terbentuk dari salah satu sumbunya yang termasuk frasa nomina seperti conto di atas.

Pola (4c) Krél + FV

Contoh:

1. Aуa nu balanja mébel (KKP/164/8/1) [ada yang belanja furniture]

2. Aya nu ngagaléntoran beungeut (KKP/121/2/2)

[ada yang menciumi wajah]

Frasa nu balanja mébel [yang belanja furniture] dan frasa $n u$ ngagaléntoran beungeut [yang menciumi wajah] dalam contoh di atas termasuk frasa relatif yang memiliki struktur unsur pertama merupakan kata sambung relatif $n u$ [yang] sebagai perangkai. Unsur kedua berupa frasa verba belanja furniture dan menciumi wajah yang merupakan sumbu atau aksisnya. Sama dengan teorinya yang menyatakan bahwa frasa relatif terbentuk dari salah satu sumbunya yang termasuk frasa verba seperti conto di atas. 
Pola (4d) Krél + FAdj

Contoh:

1. Aya deui nu leuwih hébat (KKP/47/7/4)

[ada yang lebih hebat]

2. Aya nu manis kieu (KKP/21/6/3) [ada yang manis bengini]

Frasa nu leuwih hébat [yang lebih hebat] dan frasa nu manis kieu [yang manis begini] dalam contoh di atas termasuk frasa relatif yang memiliki struktur unsur pertama merupakan kata sambung relatif $n u$ [yang] sebagai perangkai. Unsur kedua berupa frasa adjektifa lebih hebat dan manis begini yang merupakan sumbu atau aksisnya. Sama dengan teorinya yang menyatakan bahwa frasa relatif terbentuk dari salah satu sumbunya yang termasuk frasa adjektifa seperti conto di atas.

Struktur frasa relatif yang sering dipakai yaitu Krél + KS (145 frasa), struktur frasa relatif yang paling sedikit dipakai yaitu Krél + FNum (hiji frasa). Sisanya Krél + KB (115 frasa), Krél + KK (117 frasa), Krél + FN (lima frasa), Krél + FV (18 frasa), Krél + FAdj (dua frasa).

\section{Hubungan Makna Gramatikal Antarunsur Pembentuk Frasa Eksosentrik}

Frasa eksosentrik, baik frasa direktif atau frasa relatif keduanya memiliki hubungan makna gramatikal dilihat dari hubungan antar perangkai dan sumbunya.

\section{Hubungan Makna Gramatikal Frasa Direktif}

Secara semantis menurut Sudaryat (dalam Kuswari dan Hernawan, 2014, hlm. 28) menjelaskan bahwa frasa direktif atau frasa preposisi mempunyai makna yang muncul akibat penyebab bertemunya kata preposisi sebagai perangkai dan kata atau frasa lain se- bagai sumbunya. Sama dengan yang dijelaskan oleh Kosmas (2008, kc. 32) secara semantis, perangkai mempunyai hubungan makna gramatikal dengan sumbunya.

Hubungan makna gramatikal dalam frasa direktif terdapat 12 dari 14 hubungan makna gramatikal frasa direktif yang ada di antaranya makna akhir, makna alat, makna arah, makna asal, makna perbandingan, makna bahan, makna pangbarung, makna pelaku, makna pangrandap, makna sebab, makna tempat dan makna tujuan.

Hubungan makna gramatikal akhir merupakan hubungan makna gramatikal yang menunjukan hubungan makna akhir seperti dalam frasa nepi ka ayeuna [sampai sekarang].

Hubungan makna gramatikal alat merupakan hubungan makna gramatikal yang menunjukan hubungan makna alat seperti dalam frasa kana mobil [ke mobil].

Hubungan makna gramatikal arah merupakan hubungan makna gramatikal yang menunjukan hubungan makna arah seperti dalam frasa ka dapur [ke dapur].

Hubungan makna asal merupakan hubungan makna gramatikal yang menunjukan hubungan makna gramatikal asal seperti dalam frasa $t i$ hiji [dari satu].

Hubungan makna perbandingan merupakan hubungan makna gramatikal makna gramatikal yang menunjukan hubungan makna gramatikal perbandingan seperti dalam frasa batan kuring [daripada saya].

Hubungan makna bahan merupakan hubungan makna gramatikal yang menunjukan hubungan makna gramatikal bahan seperti dalam frasa ku cai tiis [oleh air dingin].

Hubungan makna pangbarung merupakan hubungan makna gramatikal yang menunjukan hubungan makna gramatikal pangbarung seperti dalam frasa jeung babaturan [bersama teman].

Hubungan makna pelaku merupakan hubungan makna gramatikal yang 
menunjukan hubungan makna gramatikal pelaku seperti dalam frasa $k u$ Akang [oleh Akang].

Hubungan makna pangrandap meru-pakan hubungan makna gramatikal yang menunjukan hubungan makna gramatikal pangrandap seperti dalam frasa $k a A a$ [ke Aa].

Hubungan makna sebab merupakan hubungan makna gramatikal yang menunjukan hubungan makna gramatikal sebab seperti dalam frasa $k u$ ambek [dengan marah].

Hubungan makna tempat merupakan hubungan makna gramatikal yang menunjukan hubungan makna gramatikal tempat seperti dalam frasa di ahérat [di aherat].

Hubungan makna tujuan merupakan hubungan makna gramatikal yang menunjukan hubungan makna gramatikal tujuan seperti dalam frasa keur barudak [untuk anak-anak].

Hubungan makna yang sering dipakai yaitu hubungan arah (119), yang paling sedikit hubungan makna perbandingan (dua), sisanya hubungan makna akhir (35), hubungan makna alat (68), hubungan makna asal (85), hubungan makna bahan (75), hubungan makna pangbarung (17), hubungan makna pelaku (76), hubungan makna pangrandap (77), hubungan makna sebab (71), hubungan makna tempat (97), hubungan makna tujuan (48).

\section{Hubungan Makna Gramatikal Frasa Relatif}

Hubungan makna dalam frasa relatif, ditemukan dua hubungan makna antaunsur pembentuknya yaitu hubungan makna milik dan hubungan makna penentu. Hubungan makna milik merupakan hubungan makna gramatikal yang menunjukan hubungan makna gramatikal milik seperti dalam frasa пи Еисеu [yang Euceu]. Hubungan makna penentu merupakan hubungan makna gramatikal yang menunjukan hubungan makna gramatikal penentu seperti dalam frasa nu anéh [yang aneh]. Hubungan makna paling banyak dipakai yaitu hubungan penentu (390) dan hubungan makna yang paling sedikit dipakai yaitu hubungan makna [milik] (13).

\section{SIMPULAN}

Berdasarkan analisis dapat disimpulkan bahwa frasa eksosentrik merupakan frasa yang terbentuk oleh unsur perangkai dan unsur sumbu. Terdapat 1133 frasa eksosentrik dengan frekuensi 1658. Frasa tersebut dikelompokkan menjadi 3, berdasarkan 1) bentuk, 2) struktur, dan 3) hubungan makna antarunsur pembentuk frasa eksosentrik.

Bentuk frasa eksosentrik merupakan jenis-jenis frasa dilihat dari perangkainya. Ada dua macam bentuk frasa eksosentrik, yaitu frasa direktif lebih banyak digunakan (770 frasa) daripada frasa relatif (430 frasa).

Dalam aspek struktur, frasa eksosentrik terdapat pola atau unsurunsur frasa eksosentrik masing-masing mempunyai pola yang tentu yaitu Prep + $\mathrm{Kx} / \mathrm{Fx}$ dan Krél $+\mathrm{Kx} / \mathrm{Fx}$. Artinya frasa direktif memiliki pola Prep $+\mathrm{Kx}$ dan Prep + Fx. Frasa relatif mempunyai pola Krél + Kx dang Krél + Fx. Frasa direktif pola Prep $+\mathrm{Kx}$ mempunyai dua subpola yaitu Prep + KB (504 frasa), dan Prep + KBil (2 frasa). Frasa direktif pola Prep + Fx mempunyai dua subpola yaitu Prep + FN (142 frasa) dan Prep + FNum (6 frasa). Frasa relatif pola Krél $+\mathrm{Kx}$ mempunyai tiga subpola yaitu Krél + KB (50 frasa), Krél +KK (148 frasa), Krél + KS (125 frasa). Frasa relatif pola Krél + Fx mempunyai empat subpola yaitu Krél + FN (11 frasa), Krél + FNum (hiji frasa), Krél + FV (41 frasa), Krél + FAdj (23 frasa).

Hubungan makna antarunsur pembentuk frasa eksosentrik merupakan hubungan makna antarunsur direktor atau relator. Terdapat 12 hubungan makna dari 14 yaitu makna akhir, makna alat, makna arah, makna asal, makna perban- 
dingan, makna bahan, makna pangbarung, makna pelaku, makna pangrandap, makna sebab, makna tempat dan makna tujuan. Selain itu, berdasarkan hasil analisis frasa relatif, terdapat dua hubungan makna antarunsur pembentuknya yaitu hubungan makna milik dan hubungan makna penentu. Hubungan makna dalam frasa eksosentrik direktif paling banyak dipakai yaitu hubungan arah, yang paling sedikit menunjukan hubungan makna perbandingan. Hubungan makna dalam frasa eksosentrik relatif paling banyak menunjukan hubungan penentu dan yang paling sedikit menunjukan hubungan makna milik.

\section{UCAPAN TERIMA KASIH}

Puji dan syukur kami panjatkan ke hadirat Ilahi Rabbi, alhamdulillah berkat rahmat-Nya, artikel ini dapat selesai. Penulis mengucapkan banyak terima kasih terhadap berbagai pihak yang telah membantu dalam penelitian ini. Semoga penelitian ini dapat bermanfaat bagi pembaca.

\section{CATATAN PENULIS}

Penulis menyatakan bahwa tidak ada konflik kepentingan terkait publikasi artikel ini. Penulis mengkonfirmasi bahwa data dan artikel ini bebas plagiarisme.

\section{PUSTAKA RUJUKAN}

Ardianto, B. (2017). Penggunaan Stuktur Frasa Eksosentris Direktif dan Fungsinya dalam Novel Negeri 5 Menara (A. Fuadi) dan Implikasinya dalam Pembelajaran Bahasa Indonesia di SMA. Jurnal Pendidikan Bahasa Dan Sastra Indonesia, 1(1), 27-43. https://doi.org/10.21009/10.21009/ AKSIS.010102

Arikunto, S. (2010). Prosedur Penelitian. Jakarta: Rineka Cipta.

Hakim, A. (2016). Bahasa dan Budaya.
TURATS, 6, No 1.

Herlis. (2007). Frasa Rélatif dina Kumpulan Carpon Oleh-Oleh Pertempuran Karangan Rukman H $S$ (Tilikan Stuktur jeung Semantis). Universitas Pendidikan Indonesia.

Kosmas, J. (2008). Frasa Preposisional dan Struktur Adjung dalam Bahasa Rongga. JURNAL ILMIAH BAHASA DAN SASTRA, IV(1).

Kuswari, U., \& Hernawan. (2014). Sintaksis Basa Sunda. Bandung: Jurusan Pendidikan Bahasa Daerah.

Najihah, M. (2015). Frasa Eksosentris dalam Novel Sebelas Patriot Karya Andrea Hirata. Universitas Muhammadiyah Surakarta.

Setyadi, A. (2017). Unsur Tambahan dalam Frasa Adjektiva. NUSA, 12(4), 186-195.

Sofyan, A. N. (2015). Frasa Direktif yang Berunsur di, dari, dan untuk dalam Bahasa Indonesia: Kajian Sintaksis dan Semantis. Sosiohumaniora, 18(3), 262-267. https://doi.org/10.24198/sosiohuma niora.v17i3.8344

Sudaryat, Y. (2013). Tata Basa Sunda Kiwari. Bandung: Yrama Widya.

Sudaryat, Y. (2014). Linguistik Umum. Bandung: Jurusan Pendidikan Bahasa Daerah Fakultas Pendidikan Bahasa dan Seni - Universitas Pendidikan Indonesia.

Sudaryat, Y. (2015). the Mindset of Sundanese People in Their Language Expressions. Indonesian Journal of Applied Linguistics, 5(1), 120. https://doi.org/10.17509/ijal.v5i1.8 39

Sugiyono. (2017). Metode Penelitian Kualitatif. Bandung: Alfabeta.

Sumarni, H. (2016). Kalimat dalam Sisindiran dan Wawangsalan Anyar 
Karya Dedy Windyagiri (Kajian Struktur dan Semantik). LOKABASA, 7 No.1, 35-43. https://doi.org/10.17509/jlb.v7i1.3 405

Sundari, W. (2017). Klasifikasi Frasa Nama-Nama Menu Makanan Berbahasa Inggris di Koran Minggu
Ini. NUSA, 12(4), 249-257. https://doi.org/10.14710/nusa.12.4. 249-257

Winarti, W. (2007). Frasa Pangantét dina Campaka Mangkak Antologi Karya nu Ngarora. Universitas Pendidikan Indonesia. 